\title{
Serous psammocarcinoma of the ovary: case report with systematic review
}

\section{Surowiczy piaszczakorak jajnika - opis przypadku i przegląd piśmiennictwa}

\author{
Ilia Mihaylov ${ }^{1}$, Angel Yordanov², Diana Strateva², Ivan Malkodanski ${ }^{3}$ \\ ${ }^{1}$ Medical University Pleven, Pleven, Bulgaria \\ 2Department of Gynaecologic Oncology, Medical University, Pleven, Bulgaria \\ ${ }^{3}$ Department of Critical Care, Medical University, Pleven, Bulgaria
}

Key words: ovarian psammocarcinoma, prognosis, treatment.

Słowa kluczowe: piaszczakorak jajnika, rokowanie, leczenie.

\begin{abstract}
Psammocarcinoma is a rare subtype of serous epithelian neoplasms arising from the ovaries and the peritoneum. It is characterized by massive psammoma body formation, low-grade cytological features, and invasiveness. We present a case of a 59-year-old female diagnosed with relapse of ovarian psammocarcinoma. She was operated 4 years previously and did not undergo chemotherapy. We performed a systematic search on this topic using the PubMed and ScienceDirect databases. In the literature 33 cases of ovarian psammocarcinoma are reported. We discuss the clinicopathological features of these patients. Ovarian psammocarcinoma is a rare and not well described disease. Due to the small number of cases found in the literature, no conclusions can be drawn about the tumour characteristics.
\end{abstract}

\section{Streszczenie}

Piaszczakorak jest rzadko występującym podtypem raka surowiczego wywodzącym się z nabłonka jajników i otrzewnej. Charakteryzuje się obecnością licznych ciałek piaszczakowatych, niskim stopniem złośliwości histologicznej oraz inwazyjnością. Przedstawiamy przypadek 59-letniej pacjentki, u której rozpoznano wznowę piaszczakoraka jajnika. Cztery lata wcześniej u chorej zastosowano leczenie chirurgiczne. Nie została poddana chemioterapii. Na potrzeby poniższej pracy dokonano przeglądu piśmiennictwa dotyczącego tego nowotworu, przeszukując bazy danych PubMed i ScienceDirect. Znaleziono łącznie 33 opisane przypadki piaszczakoraka jajnika. W artykule omówiono cechy kliniczno-patologiczne występujące $u$ pacjentek $z$ tym typem nowotworu. Piaszczakorak jajnika występuje rzadko i nie jest nowotworem dokładnie poznanym. Ze względu na niewielką liczbę przypadków opisanych w piśmiennictwie nie można wyciągnąć definitywnych wniosków dotyczących charakterystyki tego typu nowotworu.

\section{Introduction}

Psammocarcinoma is a very rare variant of serous carcinoma. It arises from the ovary or the peritoneum. It was described for the first time by Delhorme et al. in 1990 as ovarian formations with massive psammoma bodies and low-grade cytological features [1]. It has a relatively good prognosis compared to serous carcinom [1].

We present a case of recurrence of ovarian psammocarcinoma and a systematic review of the literature.

\section{Material and methods}

\section{Case report}

We present a case of a 59-year-old female diagnosed with recurrence of ovarian psammocarcinoma in the University Hospital "Georgi Stranski" Pleven. Four years previously the patient was admitted for surgery due to the formation of a $40 / 50 \mathrm{~mm}$ mass from the right ovary; laparoscopic bilateral salpingooophorectomy was performed. The histological result was psammocarcinoma from the right ovary, and the patient was staged pT1cNxMo. No chemotherapy was performed. Three years later a palpable mass was discovered in the pelvis during a gynaecological followup examination. A positron emission tomography/ computed tomography (PET/CT) discovered several lesions - an oval lesion sized $15 / 12 \mathrm{~mm}$, adhesive to the intestinal loops, a lesion $(35 / 24 \mathrm{~mm})$ covering the sigmoid colon, another lesion covering the posterior wall of the uterus and the anterior part of the rectum $-34 / 28 \mathrm{~mm}$, a lesion covering the ventral wall of the uterus of $20 / 17 \mathrm{~mm}$, and a lesion covering the angle 


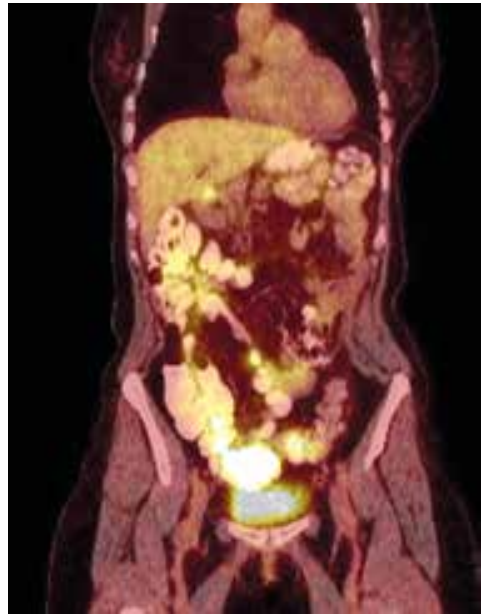

Figure 1. PET-scan image of the recurrence

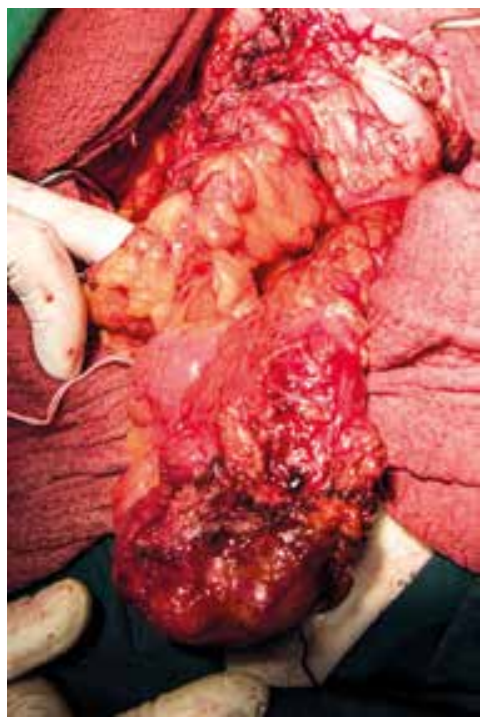

Figure 2. Intraoperative finding - the colon with the formation

- 62/36 mm. All lesions were described with high tumour calcinosis (Figure 1). Moreover, multiple calcifications on the omentum were discovered.

After the PET/CT the patient was admitted to our clinic for surgery. Debulking surgery was performed, which include hysterectomy, omentectomy, and sigmoidectomy with termino-terminal anastomosis (Figure 2). The patient underwent 6 courses of chemotherapy with paclitaxel and carboplatin. After the treatment a PET/CT examination discovered persistence of the disease in the sigmoid colon.

\section{Systematic review}

We performed a search in both the PubMed and ScienceDirect databases using the key words "psammocarcinoma ovary" and "psammocarcinoma ovarian
Table 1. Search strategy and key words

\begin{tabular}{|lccc|}
\hline Key words & $\begin{array}{c}\text { Science } \\
\text { Direct }\end{array}$ & PubMed & \\
$\begin{array}{l}\text { Psammocarcinoma } \\
\text { ovarian cancer }\end{array}$ & 57 & 48 & \\
Psammocarcinoma ovary & 60 & 46 & \\
Total & 117 & 94 & 211 \\
\hline
\end{tabular}

cancer". The search strategy and key words are presented in Table 1. For the period between January 1990 and September 2020 a total of 211 results were found. PubMed returned 46 results for "psammocarcinoma ovary" and 48 for "psammocarcinoma ovarian cancer". On the other hand, via ScieenceDirect 57 articles were found for the former key word combination and 60 for the latter. We excluded all studies and reports for psammocarcinoma from the peritoneum and duplicating articles. A multicentre study of 25 cases of psammocarcinoma of the peritoneum and ovary were additionally excluded due to the lack of specific cancer localization [1]. Finally, we analysed 33 cases described in 23 manuscripts. We paid special attention to the patient's age, cancer staging, type of surgery, chemotherapy, and recurrence.

\section{Results}

A total of 33 cases described in 23 manuscripts were in accordance with our criteria (Table 2) [2-26]. Two of them reported 4 and 8 patients, respectively, and 21 were case reports. The clinico-morphological characteristics of the patients are shown in Table 3 (all patients were staged according to FIGO classification 2009). The median age of the patients was 53 years (18-76) with the period between the fourth and fifth decades being the most hazardous. Stage III is the most common - 21 of the cases, while there was 1 case with stage II and 2 cases with stage I ovarian cancer. The most common stage by FIGO was IIIB (in 11 patients), 7 patients had stage IIIC, and 3 patients had FIGO stage IIIA. There was also a patient with stage IIC, reported by Boufettal et al. in 2012, 1 instance with stage IA ovarian cancer, and only 1 report of stage IC [2]. One case was with unknown staging. The surgical interventions differed in many cases as the age, stage of the cancer, and the circumstances differed. However, the most common was total hysterectomy with bilateral salpingo-oophorectomy, and omentectomy. In some cases, taking a biopsy from the peritoneum and lymph node dissection were performed. There are cases of debulking in order to protect the natal capabilities. The most common adjuvant chemotherapy included Carbapenem and Paclitaxel (PC therapy) 7 patients. Two females underwent neoadjuvant PC chemotherapy. Finally, 7 out of the 24 patients with follow-up either died of the disease or had recurrence. 


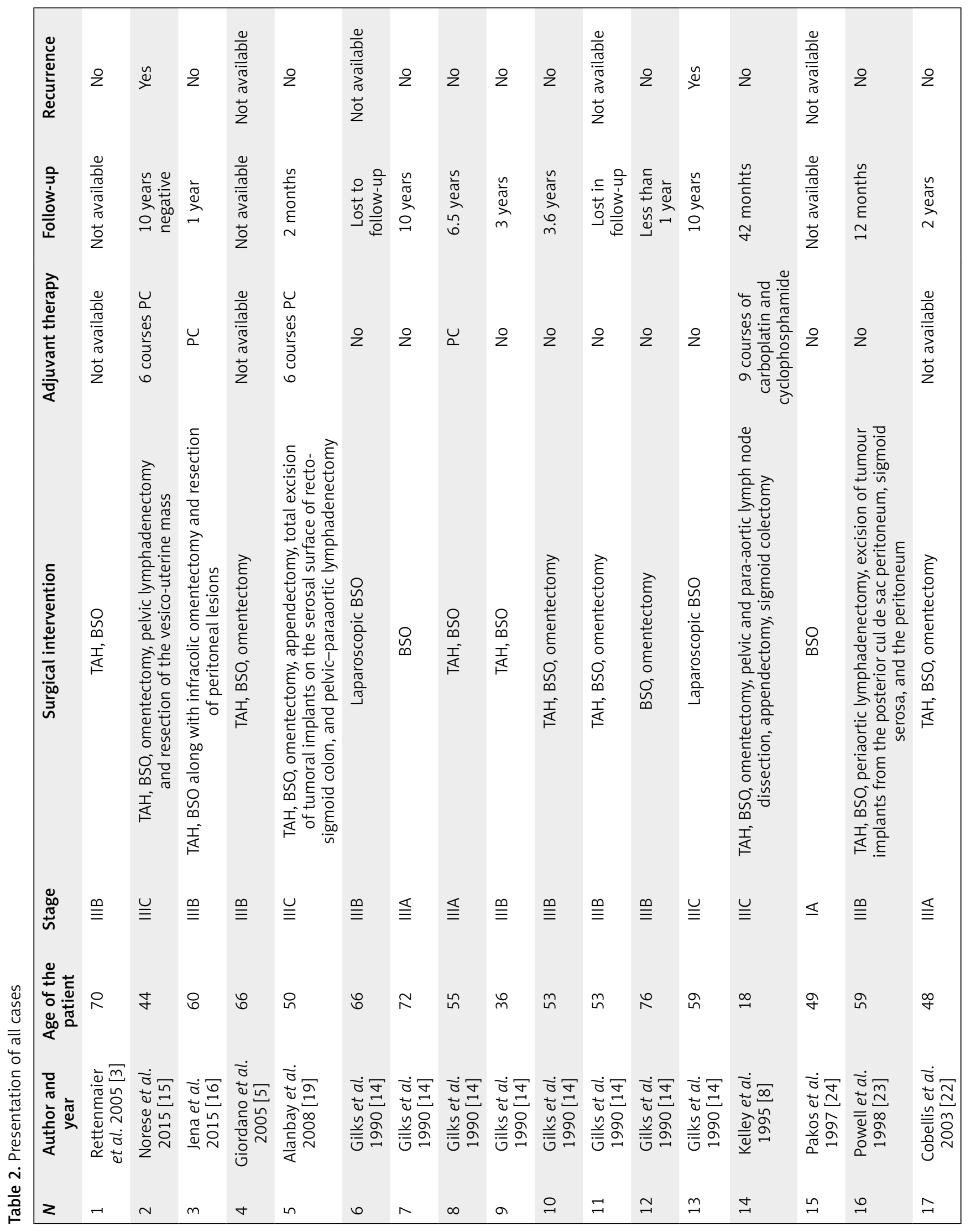




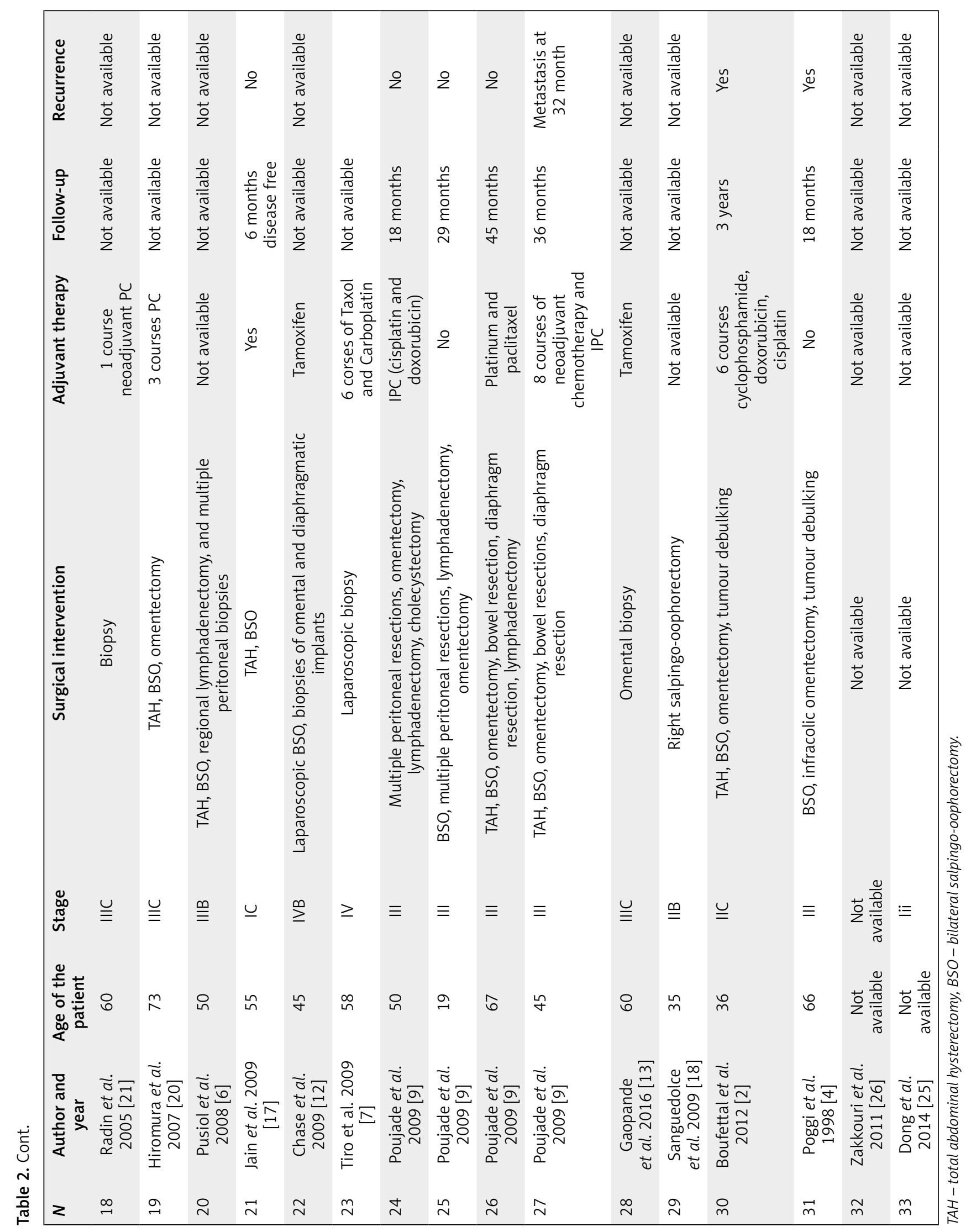




\section{Discussion}

Psammocarcinoma of the ovary is a rare subtype of serous ovarian cancer, first described by Delhorme et al. [1]. It includes a large number of psammoma bodies. These bodies are calcified spherules, found in both neoplastic and non-neoplastic tumours. Their frequent presence in tumours with mild malignant potential as well as the low recurrence rate in case reports may suggest a mild prognosis, described by authors like Rattenmaier [3]. However, some authors such as Poggi et al. in 1998 reported a bad prognosis and aggressive behaviour of the ovarian serous psammocarcinoma of the ovary [4].

Histopathologic differential diagnosis includes different types of serous epithelial tumours that have psammoma bodies; however, in this case the bodies are significantly smaller in size and are rare. In 2013 Giordano et al. reported a case of ovarian psammocarcinoma with homolateral serous cystadenoma and thecoma, associated with contralateral Brenner tumour and adenofibroma [5]. Serous psammocarcinoma (SPC) of the ovary includes a large number of well-defined psammoma bodies $-75 \%$ of the patients. In 2008 Pusiol et al. described 2 cases of ovarian cancer with psammomous bodies present [6]. One of them was a 50-year-old female with psammocarcinoma, and the other was a 56-year-old female who was diagnosed with serous adenocarcinoma when it did not respond to the diagnostic criteria set by Delhorme et al.

All of the authors described elevation of CA 125 levels. In their article from 2009 Tiro et al. presented a case of ovarian SPC with $175 \mathrm{U} / \mathrm{ml}$ [7]. The team suggested a correlation between the production of CA 125 tumour marker and the quantity of the calcifications. However, in 2015 a case of psammocarcinoma of the ovary was reported with CA $125 \mathrm{~s} 950 \mathrm{U} / \mathrm{ml}$, and in 2005 Rettenmaier et al. published a case report with CA $12525000 \mathrm{U} / \mathrm{ml}$ [3]. This goes to prove that the tumour marker is no way correlated with the psammoma bodies. In a case report from Kelley et al. published in 1995, an 18-year-old patient with ovarian SPC, staged IIIC, was described with $25 \mathrm{U} / \mathrm{ml}$ [8]. Thereby, there is no connection between the CA 125 elevation and the psammoma bodies.

We discovered a significant number of cases of recurrence in the literature. Norese et al. reported a patient with long-term recurrence [15]. The patient developed psammocarcinoma of the rectum 10 years after the treatment. Tiro et al. described a patient with implants in the pleural cavity and the pericardium [7]. Poggi et al. described the aggressive nature of the disease as highly metastatic [4]. They reported multiple metastatic nodules covering both the peritoneum and the intestines. A histopathological examination recognizes the nodules as psammocarcinoma similar to the patient's first diagnosis. Poujade et al. described a case series of 4 patients with ovarian SPC and 1 pa-
Table 3. Clinico-morphological characteristics of the patients

\begin{tabular}{|c|c|}
\hline Clinico-morphological features & Value \\
\hline \multicolumn{2}{|l|}{ Age [years]: } \\
\hline Median age (18-76); & 52.8 \\
\hline Patients aged 11-20; & $2(6.25 \%)$ \\
\hline Patients aged 31-40; & $3(9.4 \%)$ \\
\hline Patients aged 41-50; & $8(25 \%)$ \\
\hline Patients aged 51-60; & $10(32.25 \%)$ \\
\hline Patients aged 61-70; & $5(14.3 \%)$ \\
\hline Patients aged $70-80$ & $3(9.4 \%)$ \\
\hline \multicolumn{2}{|l|}{$\begin{array}{l}\text { Stage (according to FIGO } \\
\text { classification from 1998): }\end{array}$} \\
\hline I & $4(12.5 \%)$ \\
\hline$\|$ & $2(6.25 \%)$ \\
\hline III & $24(75 \%)$ \\
\hline IV & $2(6.25 \%)$ \\
\hline \multicolumn{2}{|l|}{ Surgical procedure: } \\
\hline Optimal/suboptimal & $28(87.5 \%)$ \\
\hline Biopsies & $3(9.375 \%)$ \\
\hline Unknown & $1(3.125 \%)$ \\
\hline \multicolumn{2}{|l|}{ Lymph node dissection: } \\
\hline Total & $8(25 \%)$ \\
\hline Negative & $6(75 \%)$ \\
\hline Positive & $2(25 \%)$ \\
\hline \multicolumn{2}{|l|}{ Chemotherapy: } \\
\hline Yes & $15(46.875 \%)$ \\
\hline No & $11(34.375 \%)$ \\
\hline Unknown & $6(18.75 \%)$ \\
\hline Recurrence & $6(18 \%)$ \\
\hline Death of disease & $1(3.125 \%)$ \\
\hline
\end{tabular}

tient with peritoneal psammocarcinoma [9]. One of the patients with ovarian cancer referred to their clinic at the time of the third recurrence of the disease.

Ovarian cancer is the eighth most common malignancy in women. It is most commonly seen in Eastern Europe, with Serbia taking the first place, according to the American Institute for Cancer Research.

The Ovarian Cancer Research Alliance claims that the median age of diagnosing patients is 63 years - the 55-64 interval being the most prominent for developing ovarian cancer [10]. After careful research our team discovered that the median age for diagnosing psammocarcinoma of the ovary is 53 years. Thus, psammocarcinoma affects significantly younger women. 
Ovarian cancer treatment depends on the stage.

Stage I ovarian cancer treatment differs in IA and IB on the one hand and IC on the other. IA and IB depends on the tumour grade. Grade 1 ovarian tumours do not need postsurgical treatment. In premenopausal females it is optional to remove only the ovary, containing the cancer along with the fallopian tube on the same side. Treating grade 2 tumours may include 3-6 cycles of chemotherapy, usually standard PC therapy that includes carboplatin and paclitaxel. Grade 3 is similar to grade 2 . Stage IC treatment also resembles stage IA and IB grade 2 ovarian tumour treatment. Stage II ovarian tumour treatment includes surgery and chemotherapy. It starts with surgery for staging and debulking - hysterectomy and bilateral salpingo-oophorectomy. The goal is to remove as much of the tumour as possible. Chemotherapy includes 6 cycles of carboplatin and paclitaxel. In some cases, intraperitoneal (IP) chemotherapy is performed instead of intravenous (IV) therapy. Most of the cases of ovarian SPC described in the literature are staged IIIC, which speaks for its aggressive nature. Treating stage III cancer combines chemotherapy and surgical treatment. Surgical treatment consists of removing the uterus, both of the fallopian tubes and ovaries, the omentum, and lymph node dissection. The goal of surgical treatment is to stage the disease properly as well as to remove all traces of visible tumour or no tumour larger than $1 \mathrm{~cm}$.

Afterwards the patient undergoes adjuvant chemotherapy. It can be both IV and IP. The chemotherapy usually includes a combination of 2 drugs: a platinum compound such as cisplatin and carboplatin and a taxan - paclitaxel or docetaxel. A typical treatment involves 3-6 cycles. A cycle includes a regular application and a rest period, individual for the drug. In cases of stage III ovarian cancer IP therapy could be applied in conjunction with IV drugs. A condition for intraperitoneal chemotherapy is for the cancer to be optimally debulked and not spread outside of the abdomen. Side effects are often severe. They include abdominal pain, nausea, vomiting, and others. In cases of inability to perform surgery, neoadjuvant chemotherapy is performed. Its purpose is to reduce the size of the tumour and to allow surgical intervention. Maintenance therapy is an innovative approach. It is performed in cases of successful surgery and chemotherapy. Drugs that may be used include bevacizumab or a PARP (poly(ADP)-ribose polymerase) inhibitor. Stage IV ovarian cancer is characterized by distant sides metastases such as liver, lungs, bones, and spleen. Treatment is similar to stage III. Surgery is used to remove the tumour and debulk the cancer, followed by chemotherapy and target therapy - a kind of treatment that uses drugs that identify and attack target molecules in the cancer cells. Target therapy uses bevacizumab or a PARP inhibitors like mainte- nance therapy [11]. Of the 22 patients staged by FIGO only 16 underwent total hysterectomy. There were 3 more cases of radical operation where the cancer staging was unavailable. Kelley et al. reported a case of an 18-year-old patient, in which they chose a debulking approach despite the late staging in order to preserve her fertility [8].

There are data for only 15 patients to have chemotherapy applied. Six of said patients had PC therapy applied, 2 underwent neoadjuvant chemotherapy, 2 accepted treatment with tamoxifen $[12,13]$, and 2 were treated via IPC (intraperitoneal chemotherapy) [9].

Recurrence is the process of cancer returning. Recurrences can be local or distant based on the location of the primary cancer. Treatment of recurrent cancer may include surgery and chemotherapy. It is believed that the longer it takes the recurrences to manifest, the milder the prognosis is. The chemotherpy drugs in cases of recurrence of ovarian cancer are different depending on the location of the recurrence itself as well as the time period after the initial treatment of the primary ovarian cancer. It is possible to apply drugs for target therapy as well as hormonal treatment. It is possible to treat a patient with standard adjuvant therapy if they have not received it during the initial treatment.

In our case, 4 years after the initial surgical treatment, the patient returned with multiple tumour lesions in the pelvis and abdomen. Chemotherapy was not applied after the laparoscopic bilateral salpingooophorectomy; however, having the literature in mind, there is no proof that adjuvant chemotherapy increases the chances of successful treatment.

\section{Conclusions}

The aetiology and clinical behaviour of ovarian psammocarcinoma is not well-known. Some authors reported that it has tumours behaviour similar to serous borderline, but others disagree. Sometimes it is an aggressive tumour with bad prognosis. Due to the rarity of the disease, it is safe to say that there is no guideline for the treatment of this carcinoma. Therefore, the best we could do is to treat it according to the ovarian cancer treatment guidelines.

\section{Acknowledgments}

We sincerely thank Ivan Mihaylov MD.

\section{Conflict of interest}

The authors declare no conflict of interest.

\section{References}

1. Delhorme JB, Ohayon J, Gouy S, Gouy S, Averous G, Genestie C, Gaichies L, Glehen O, Guilloit JM, Pezet D, Quenet F, Ferron G, Brigand C, Morice P, Honoré C, French Network for Rare Peritoneal Malignancies (RENAPE). 
Ovarian and peritoneal psammocarcinoma: results of a multicenter study on 25 patients. Eur J Surg Oncol 2020; 46: 862-867.

2. Boufettal H, Noun M, Hermas S, Samouh N. Intramammary metastasis of a psammocarcinoma of the ovary. Diagn Interv Imaging 2012; 93: 64-66.

3. Rettenmaier MA, Goldstein BH, Epstein HD, Brown JV Micha JP. Serous psammocarcinoma of the ovary: an unusual finding. Gynecol Oncol 2005; 99: 510-511.

4. Poggi SH, Bristow RE, Nieberg RK, Berek JS. Psammocarcinoma with an aggressive course. Obstet Gynecol 1998; 92 (4 II Suppl.): 659-661.

5. Giordano G, Gnetti L, Milione M, Piccolo D, Soliani P. Serous psammocarcinoma of the ovary: a case report and review of literature. Gynecol Oncol 2005; 96: 259-262.

6. Pusiol T, Parolari AM, Piscioli I, Morelli L, Del Nonno F, Licci S. Prevalence and significance of psammoma bodies in cervicovaginal smears in a cervical cancer screening program with emphasis on a case of primary bilateral ovarian psammocarcinoma. Cytojournal 2008; 5: 7.

7. Tiro AV, Talukdar R, Lewis MG. A unique case of serous psammocarcinoma of the ovary presenting with pleural effusion and manifesting psammoma body implants in the pleural cavity and pericardium. Gynecol Oncol 2009; 113: $402-404$

8. Kelley JL, Capelle SC, Kanbour-Shakir A. Serous psammocarcinoma of the ovary in an adolescent female. Gynecol Oncol 1995; 59: 309-311.

9. Poujade O, Uzan C, Gouy S, Pautier P, Duvillard P, Morice P. Primary psammocarcinoma of the ovary or peritoneum. Int J Gynecol Cancer 2009; 19: 844-846.

10. Ovarian Cancer Statistics. Ovarian Cancer Research Alliance. Accessed October 22, 2020. https://ocrahope.org/ patients/about-ovarian-cancer/statistics/

11. Treating Ovarian Cancer.

12. Chase DM, Sparks DA, Gener M, Smith J. A unique case of ovarian psammocarcinoma with mediastinal, pulmonary, subcutaneous, and omental metastases. Arch Gynecol Obstet 2009; 280: 283-286.

13. Gaopande VL, Joshi AR, Pathak GS, Gogate BP. Immunohistochemical study of ovarian psammocarcinoma: report of a rare case. Taiwan J Obstet Gynecol 2016; 55: 299-300.

14. Gilks CB, Bell DA, Scully RE. Serous psammocarcinoma of the ovary and peritoneum. Int J Gynecol Pathol 1990; 9: $110-121$.

15. Norese G, Moreira A, Alessandria S, Gorosito F, Lange MJ, Bermudez A. Serous psammocarcinoma of the ovary and peritoneum: long term recurrence. Int J Gynecol Cancer 2015; 25: 65.

16. Jena SK, Mishra P, Mohapatra V, Singh S. Bilateral serous psammocarcinoma of ovary: rare variant low grade serous carcinoma. Case Rep Obstet Gynecol 2015; 2015: 531242.

17. Jain D, Akhila L, Kawatra V, Aggarwal P, Khurana N. Psammocarcinoma of ovary with serous cystadenofibroma of contralateral ovary: a case report. J Med Case Rep 2009; 3: 9330.

18. Sanguedolce F, Indraccolo U, Tortorella S, Nappi L, Rosenberg P, Greco P, Bufo P. A case of ovarian psammocarcinoma associated with endometrioid cysts: a morphological and immunohistochemical study. Tumori 2009; 95: 112-114.
19. Alanbay I, Dede M, Üstün Y, Karaşahin E, Deveci S, Günhan O, Yenen MC. Serous psammocarcinoma of the ovary and peritoneum: two case reports and review of the literature. Arch Gynecol Obstet 2009; 279: 931-936.

20. Hiromura T, Tanaka YO, Nishioka T, Tomita K. Serous psammocarcinoma of the ovary: CT and MR findings. J Comput Assist Tomogr 2007; 31: 490-492.

21. Radin AI, Youssef IM, Quimbo RD, Perone RW, Guerrieri C, Abdel-Dayem HM. Technetium-99m diphosphonate imaging of psammocarcinoma of probable ovarian origin case report and literature review. Clin Nucl Med 2005; 30: 395-399.

22. Cobellis L, Pezzani I, Cataldi P, Bome A, Santopietro R, Petraglia F. Ovarian psammocarcinoma with peritoneal implants. Eur J Obstet Gynecol Reprod Biol 2003; 107: 217-219.

23. Powell JL, McDonald TJ, White WC. Serous psammocarcinoma of the ovary. South Med J 1998; 91: 477-480.

24. Pakos E, Funke A, Tschubel K, Pfeifer U. Seroses psammokarzinom des ovars: Fallbericht und literaturubersicht. Pathologe 1997; 18: 463-466.

25. Dong A, Wang Y, Zuo C. FDG PET/CT in serous psammocarcinoma of the ovary. Clin Nucl Med 2014; 39: 453-455.

26. Zakkouri FA, Berrada N, Kettani F, Mrabti H, Jali A, Errihani H. Aggressive ovarian psammocarcinoma: a case report. Eur J Gynaecol Oncol 2011; 32: 214-215.

\section{Address for correspondence:}

Angel Danchev Yordanov $\mathrm{PhD}$

Department of Gynaecologic Oncology

Medical University

Pleven, Bulgaria

E-mail: angel.jordanov@gmail.com 